Revista Iberoamericana, Vol. LXIX, Núm. 204, Julio-Septiembre 2003, 729-730

\title{
Y CUANDO DESPERTAMOS, AUGUSTO MONTERROSO (1921-2003) TODAVÍA ESTÁ ALLÍ
}

\author{
POR \\ Ignacio Sánchez PRado \\ University of Pittsburgh
}

La primera vez que leí la historia de esa proverbial oveja negra fusilada e institucionalizada, pensé ingenuamente que el autor de la fábula tenía que ser una suerte de sabio inmortal, un hombre que escribió desde las profundidades de los tiempos y cuya sabiduría llegó inexplicablemente hasta nuestros días. Posteriormente, ya lejos de esos días de credulidad, me enteré de que la escribió un tal Augusto Monterroso, que no solo tenía la enorme virtud de estar vivo, sino que además era autor de un pequeño e intenso mundo literario. Ese descubrimiento me causó una enorme alegría, que se fue complementando cada vez que pasaba por mis manos uno de sus textos. El motivo de mi alegría era el profundo asombro que me causaba saber que en estos días llenos de oscuridad existía un hombre para el cual la palabra era una forma de libertad y su literatura una sabiduría que, pese a la miopía contemporánea, todavía era capaz de embotellar mensajes para lanzarlos al mar del mundo. El 7 de febrero, sin embargo, descubrí con profunda tristeza que Augusto Monterroso era una maravilla tan efímera como la vida de un hombre y que su muerte significaba perder un poco esa dimensión donde la palabra no es la atadura insuficiente que sufrimos todas las personas sino un instrumento versátil que, desde su insospechada transparencia, es todavía capaz de decirnos lo que hemos sabido toda la vida.

La libertad de Augusto Monterroso se extendió a los criterios geográficos. Nacido en Tegucigalpa, de nacionalidad guatemalteca y residencia mexicana, Monterroso fue uno de esos raros ciudadanos del mundo, capaces de pertenecer a América Latina con la falta de determinismo que sólo se puede permitir un fabulista. Monterroso comprendió por qué la rana que quería ser rana terminó pareciendo pollo o los motivos que impidieron al burro y a la flauta asumir la grandeza de su momento juntos. Ese carácter de exiliado constante le permitió decirnos por qué el viejo organista de barrio guatemalteco renunció a dar a conocer al mundo su descubrimiento de la sinfonía inconclusa de Schubert y su profundo conocimiento de lo humano lo llevó a retratar el dolor del padre que sufría la prodigiosa vocación musical de su hija. Y, por supuesto, imposible olvidar a Eduardo Torres, protagonista de Lo demás es silencio, en quien conocimos todas las sutilezas de esos intelectuales latinoamericanos de provincia que amamos y odiamos a la vez. Sólo Augusto Monterroso pudo contar con tanta precisión esas historias que todos conocemos y que forman parte de nuestra educación sentimental incluso antes de confirmarlas en sus páginas. 
Hoy la voz de Monterroso parece haber quedado apagada. Sin embargo, su obra nos permitirá saber que cuando despertemos de todas nuestras pretensiones intelectuales Augusto Monterroso todavía estará allí para darnos, a través de la lectura, el inusitado don de la libertad. 